\title{
Marker assisted selection for Rust resistant gene LR26 in Wheat (Triticum aestivum L.)
}

\author{
Liaqat $\mathrm{Ali}^{1}$, Inam Ullah ${ }^{2}$, Siraj ud Din ${ }^{3}$, Wisal Muhammad Khan ${ }^{4 *}$, \\ Muhammad Saleem Khan ${ }^{4}$, Izhar Ahmad ${ }^{4}$, Mursaleen ${ }^{4}$, Maqsood Anwar ${ }^{4}$ \\ and Waqar $\mathrm{Ali}^{5}$ \\ 1. Department of Botany, Hazara University, Mansehra, Pakistan. \\ 2. Department of Genetics, Hazara University, Mansehra, Pakistan. \\ 3. Department of Botany, University of Peshawar, Pakistan. \\ 4. Department of Botany, Islamia College Peshawar, Pakistan. \\ 5. Department of Biotechnology,University of Malakand., Pakistan \\ *Corresponding author's email: wisalmadani@hotmail.com \\ Citation \\ Liaqat Ali, Inam Ullah, Siraj ud Din, Wisal Muhammad Khan, Muhammad Saleem Khan, Izhar Ahmad, Mursaleen, \\ Maqsood Anwar and Waqar Ali Marker assisted selection for Rust resistant gene LR26 in Wheat (Triticum aestivum \\ L.). Pure and Applied Biology. Vol. 4, Issue 3, 2015, pp 302-305. http://dx.doi.org/10.19045/bspab.2015.43004
}

Received: $25 / 04 / 2015$

Revised: 04/07/2015

Accepted: $10 / 07 / 2015$

\section{Abstract}

Wheat is an important cereal crop of Pakistan which is adversely affected by Puccinia species in some cultivated zones of the country. Therefore, thirty eight wheat (Triticum aestivum L.) genotypes were assessed for the presence of $\operatorname{Lr} 26$ gene through polymerase chain reaction analysis. The STS marker iag95 was used for the identification of $L r 26$ gene. A diagnostic band of 1000bp was amplified in five genotypes viz., Bakhar 2008, Khyber 79, Mehran 89, Potohar 70, and Zarlashta 90. These genotypes are recommended for use in breeding rust resistance wheat genotypes and gene pyramiding.

Key words: Leaf rust; Lr 26 gene; STS primer; Triticum aestivum L.

\section{Introduction}

Wheat is an important cereal crop of the Pakistan. Being a staple diet, it is cultivated on the largest area in almost every part of the world, in a wide range of climatic zones. The occurrence of diseases is a serious threat to its low yield and varietal deterioration. Leaf rust (Puccinia triticina Eriks.) is one of the most damaging foliar pathogens of wheat. Epidemics of rusts, sometimes caused by new pathogen races, frequently affect wheat grain production and quality throughout the world.
Sources of genetic resistance are valuable to increase the sustainability of cereal production, from both economic and environmental standpoints [1]. Genetics of leaf rust resistance has long been studied in wheat, especially hexaploid wheat (Triticum aestivum L.), where ca. $58 \mathrm{Lr}$ genes have been identified [2]. A number of these genes have been characterized for differential reaction to single leaf rust isolates and mapped to wheat chromosome (chr.) arms [3]. Most of these genes belong to the racespecific gene class where the incompatible interaction is controlled by a relatively 
simple gene-for-gene recognition pattern (hypersensitive resistance). As a consequence, single R-genes are easily overcome by rapidly changing Puccinia triticina populations with the spread of new virulent pathotypes [4]. Obtaining cultivars with durable resistance is a major target for wheat geneticists and breeders. For this purpose, two approaches have been suggested: (1) pyramiding more than two $\mathrm{Lr}$ genes, mainly through marker-assisted selection [5] and (2) pursuing the genetic characterization and mapping of durable resistance factors. Nowadays the $L r$ genes can be identified with the use of molecular markers, such as sequence-tagged site (STS), sequence-characterized amplified regions (SCAR), cleaved amplified polymorphic sequences (CAPS), and simple sequence repeat (SSR). We used STS marker to detect $\mathrm{Lr} 26$ gene in different wheat genotypes to be used for gene pyramiding against leaf rust.

\section{Materials and Methods}

Thirty eight genotypes of common wheat (Triticum aestivum L.) were grown in the field and examined for leaf rust resistance gene $L r$ 26. Total genomic DNA was isolated from leaf samples using the method of Weining and Langridge [6]. PCR was performed in a total volume of $15 \mu \mathrm{l}$ containing 50ng of genomic DNA, 1XPCR buffer, $10 \mu \mathrm{M}$ of each (FCTCTGTGGATAGTTACTTGATCGA and R-CCTAGAACATGCATGGCTGTTACA) STS primers, $10 \mathrm{mM}$ of each deoxyribonucleotides, $3.5 \mathrm{mM} \mathrm{MgCl}_{2}, 1 \mathrm{U}$ of Taq DNA Polymerase (Fermentas). The PCR was carried out using thermal cycler, as follows: Initial denaturation of $94^{\circ} \mathrm{C}$ for 3 minutes; 30 cycles of $94^{\circ} \mathrm{C}$ for 30 seconds, $56^{\circ} \mathrm{C}$ for 60 seconds, $72^{\circ} \mathrm{C}$ for 70 seconds and 1 cycle of $25^{\circ} \mathrm{C}$ for 60 seconds and then hold at $4^{\circ} \mathrm{C}$. The PCR product was electrophoresed on 1\% agarose gels, stained with Ethidium bromide and photographed by U-Vitec gel documentation system.

\section{Results}

Molecular marker used to identify the Lr26 leaf rust resistance gene in different wheat genotypes. It was linked with the resistance gene and detected by PCR (Figure 1). For this study, we used thirty eight different wheat genotypes obtained from different locations in Pakistan. It was observed that in out of these thirty eight genotypes of wheat the $\operatorname{Lr} 26$ gene was found in five genotypes i.e. Bakhar 2008, Khyber 79, Mehran 89, Potohar 70 and Zarlashta-90 (Table 1).

\section{Discussion}

The STS marker iag95 made possible immediate identification of genes $\operatorname{Lr} 26$ in the studied genotypes. A characteristic fragment of approximately $1000 \mathrm{bp}$ with the use of the iag95 marker were identified in genotypes Bakhar 2008, Khyber 79, Mehran 89, Potohar 70 and Zarlashta 90. Rye (Secale cereale L.) is the source of the $\mathrm{Lr} 26$ gene. Urbanovich et al., [7] studied sixty eight different wheat genotypes which were obtained from different countries and out of these sixty eight genotypes eleven genotypes were found having $\operatorname{Lr} 26$ gene. Gultyaeva et al., [8]. also studied 100 winter, and 131 Spring Russian wheat genotypes for identification of various leaf rust resistance genes with the help of molecular markers and $\operatorname{Lr} 26$ gene was found in only $10 \%$ of the genotypes. $\operatorname{Lr} 26$ is not so much as compared to other $\mathrm{Lr}$ genes and the main reason for this is that actually it is not from the wheat ( Triticum aestivum L) origin, it is from rye (Secale cereale L.) origin. The screening of Lr26 in common wheat genotypes will help in the development of rust resistant genotypes and gene pyramiding. 


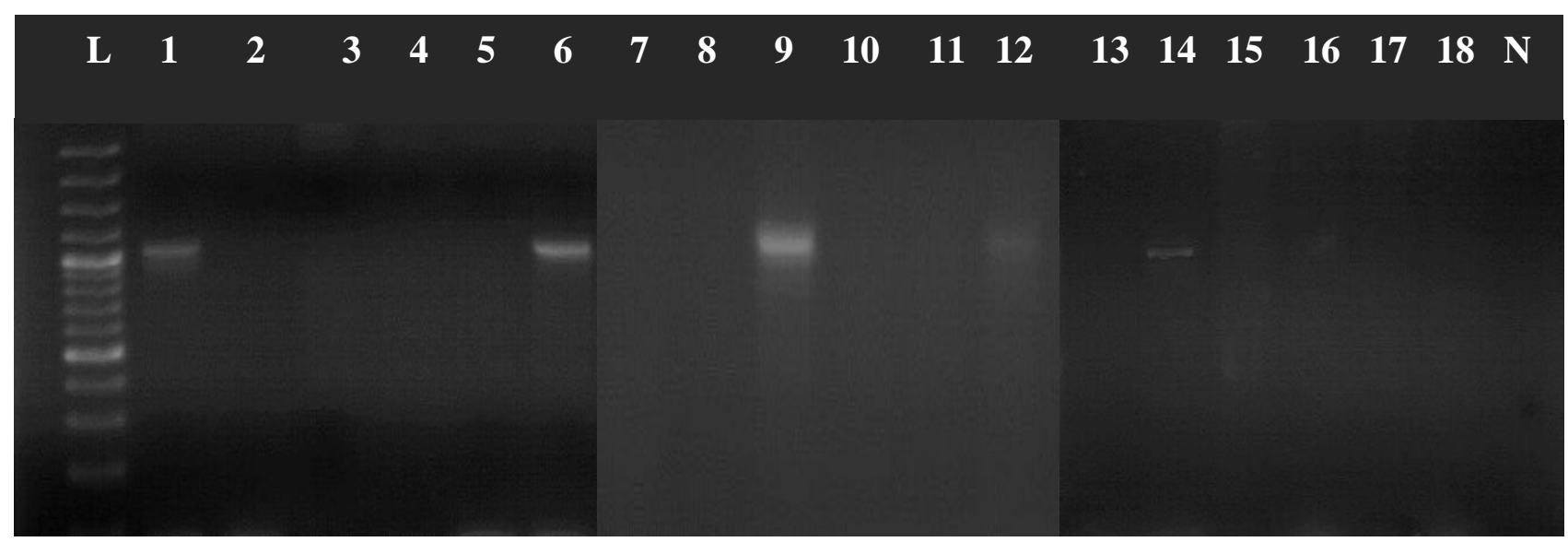

Figure-1. PCR amplification profile of $\operatorname{Lr} 26$ gene in different wheat genotypes.

Ladder100 bps (L), (1) Bakhar-2008, (2) Wafaq-2008, (3) Kohinor-83, (4) Merco- 2007, (5) Saleem-2000, (6) Khyber-79, (7) Sind-81, (8) Sariab-92, (9) Mehran-89, (10) Drawar-96, (11) Margalla-99, (12) Potohar-70, (13) GA-2002, (14) Zarlashta-90, (15) C-273, (16) Chanab-96, (17) Punjab-96, (18) Haider- 2002 and Negative control (N).

Table 1. The Lr26 leaf rust resistance gene presence [+] and absence [-] in different wheat genotypes.

\begin{tabular}{|c|c|c|c|c|c|}
\hline S.No & Genotype & Lr26 gene & S.No & Genotype & Lr26 gene \\
\hline 1 & Bakhar 2008 & + & 20 & Nayab-83 & - \\
\hline 2 & Wafaq 2008 & - & 21 & Raskoh & - \\
\hline 3 & Kohinoor 83 & - & 22 & Abdghar-93 & - \\
\hline 4 & Merco 2007 & - & 23 & Chenab-70 & - \\
\hline 5 & Saleem 2000 & - & 24 & Manther & - \\
\hline 6 & Khyber 79 & + & 25 & KSK & - \\
\hline 7 & Sindh-81 & - & 26 & MH-97 & - \\
\hline 8 & Sariab-92 & - & 27 & Local white & - \\
\hline 9 & Mehran-89 & + & 28 & Noshera 96 & - \\
\hline 10 & Drawar-96 & & 29 & Fasalabad 83 & - \\
\hline 11 & Margalla-99 & - & 30 & Ronthas 90 & - \\
\hline 12 & Potohar-70 & + & 31 & Barani 70 & - \\
\hline 13 & GA-2002 & - & 32 & Faisalabad 85 & - \\
\hline 14 & Zarlashta-90 & + & 33 & Zarghun 79 & - \\
\hline 15 & C-273 & - & 34 & YR 5 & - \\
\hline 16 & Chenab-96 & - & 35 & YR & - \\
\hline 17 & Punjab-96 & - & 36 & LR 51 + YR & - \\
\hline 18 & Haider-2002 & - & 37 & Anza+ 2 NS & \\
\hline 19 & C-228 & - & 38 & $1036+L R$ 51 + YR & \\
\hline
\end{tabular}




\section{References}

1. Reynolds MP and Borlaug NE (2006). Impacts of breed in international collaborative wheat improvement. $J$. Agric. Sci. 144: 3-17.

2. Kolmer JA (1996). Genetics of resistance to wheat leaf rust. Annu Rev Phytopathol. 34:435-455.

3. McIntosh RA, Wellings CR and Park RF (1995). Wheat Rusts: An Atlas of Resistance Genes, Melbourne: CSIRO.

4. Kolmer JA, Jin Y and Long DL (2007). Wheat leaf and stem rust in the UniteStates. Aust. J. Agric. Res. 58:631-638.

5. Chelkowski J and Stepien L (2001). Molecular markers for leaf rust resistance genes in wheat. J. Appl. Genet. 42:117-126.
6. Weining $S$ and Langridge $P$ (1992). Identification and mapping of polymorphism in cereals base on polymerase chain reaction. Theor. Appl. Genet. 82: 209-216.

7. Urbanovich OY, Malyshev SV, Dolmatovich TV and Kartel NA (2006). Identification of Leaf Rust Resistance Genes in Wheat (Triticum aestivum L.) Cultivars Using Molecular Markers. Genetika 42(5): 675-683.

8.Gultyaeva EI, Kanyuka IA, Alpat'eva NV,Baranova OA, Dmitriev AP and Pavlyushin VA (2009). Molecular Approaches in Identifying Leaf Rust Resistance Genes in Russian Wheat Genotypes. Russian Agri. Sci. 35(5):316-319. 